\title{
GLOBAL CRISIS
}

Geoffrey Parker is a renowned British historian who taught at the University of St Andrews, the University of Illinois, the University of British Columbia, and Yale University, before becoming Andreas Dorpalen Professor of European History and Associate of the Mershon Center at The Ohio State University. He is a Fellow of the British Academy, the Netherlands Academy of Arts and Sciences, the Spanish-American Academy of Arts and Sciences (Cadiz), the Royal Academy of History (Madrid), and the Royal Society of Edinburgh. He is also a Profesor Afiliado in the División de Historia at the Centro de Investigación y Docencia Económicas, Mexico City. His many books include The Military Revolution (1988; winner of the best book prize of the American Military Institute and the Society for the History of Technology), The Grand Strategy of Philip II, published by Yale in 1998 (winner of the Samuel Eliot Morison Prize), and, most recently, Imprudent King: A New Life of Philip II, published by Yale in 2014. In 2012, the Royal Dutch Academy awarded Parker its biennial Heineken Foundation Prize for History, open to scholars in any field and any period, from any country; two years later, he won a medal awarded by the British Academy for 'a landmark academic achievement ... which has transformed understanding of a particular subject' for Global Crisis. 


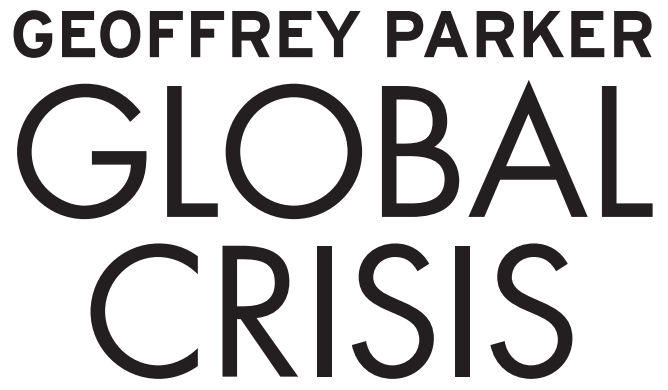

WAR, CLIMATE CHANGE AND CATASTROPHE IN THE SEVENTEENTH CENTURY

ABRIDGED AND REVISED EDITION 
Copyright (C) 2017 Geoffrey Parker

Original hardback edition published 2013

All rights reserved. This book may not be reproduced in whole or in part, in any form (beyond that copying permitted by Sections 107 and 108 of the U.S. Copyright Law and except by reviewers for the public press) without written permission from the publishers.

For information about this and other Yale University Press publications, please contact:

U.S.Office: sales.press@yale.edu_yalebooks.com

Europe Office: sales@yaleup.co.uk yalebooks.co.uk

Set in Minion Pro by IDSUK (DataConnection) Ltd

Printed in Great Britain by Hobbs the Printers, Totton, Hampshire

Library of Congress Cataloging-in-Publication Data

Names: Parker, Geoffrey, 1943- author.

Title: Global crisis : war, climate change and catastrophe in the seventeenth century / Geoffrey Parker.

Description: Abridged edition. | New Haven : Yale University Press, 2017. | Includes bibliographical references and index.

Identifiers: LCCN 2017005476 (print) | LCCN 2017008357 (ebook) | ISBN 9780300219364 (paperback) | ISBN 9780300226355 ()

Subjects: LCSH: History, Modern-17th century. | Military history-17th century. |

Civil War-History-17th century. | Revolutions-History-17th century. |

Climatic changes-Social aspects-History-17th century. |

Disasters-History-17th century. | BISAC: HISTORY / World. | HISTORY /

Modern / 17th Century.

Classification: LCC D247 .P37 2017 (print) | LCC D247 (ebook) | DDC 909/.6-dc23

LC record available at https://lccn.loc.gov/2017005476

A catalogue record for this book is available from the British Library.

10987654321 
This book is dedicated in admiration to all who fight multiple sclerosis 


\section{'Global Crisis Cruelly Abridged’}

And the earth did spin.

An orb far from warming light.

Cast in a dark pall.

From the sun it came;

Wave on wave, chilling absence.

Crops stunted in bloom.

The hardship spread fast.

The golden age did not last.

Rulers toppled first.

Out in barley fields,

Where farmers could scrounge no meals,

Hear the beating drum!

Headless was the king.

And the historians sing:

The weather! Really?

Bah...

Richard PARKer, January 2014

Composed upon learning that Gregory C. Johnson, an oceanographer, had distilled the 2,000-page IPCC Fifth Assessment Report into nineteen haiku 